IKONOMIKA: Journal of Islamic Economics and Business

Volume 2, No I (20I7)

ISSN: 2527-3434 (PRINT) - ISSN: 2527-5I43 (ONLINE)

Page : $85-92$

\title{
Entrepreneurial Management Coastal Muslim In The Village Bongo Gorontalo
}

\author{
Abdul Rahmat \\ Gorontalo State University \\ abdulrahmat@ung.ac.id
}

\begin{abstract}
The aim of this research activities to proving the entrepreneurial management of the coastal Muslim community in the village of Bongo. Experimental design used in this research is quasi experiment with the design of "The One-group pre-test - Post-test Design". The results showed that the model of functional skills for women of fishermen in the village of Bongo district of Gorontalo, can be seen from several aspects, namely: (I) The control / understanding of learners (female fisherman in the village of Bongo) of the learning materials functional skills wives of the fishermen in the form of entrepreneurship, practice makes kolombengi taste of fish, practice makes fish nuggets and practice makes sticks corn fish. (2) understanding wives of the fishermen village of Bongo towards community empowerment programs and Improved skills of students in the field of entrepreneurship, especially in terms of business development and business administration, and (3) the ability of learners work together in a business group that can produce a product with the criteria and processes in place.
\end{abstract}

Keywords: Entrepreneurial Management, Coastal Muslim Community, Experimental Design

\begin{abstract}
Abstrak
Penelitian ini bertujuan untuk membuktikan pengelolaan kewirausahaan pada masyarakat muslim pesisir di Desa Bongo. Desain eksperimen yang dipergunakan dalam penelitian ini ialah eksperimen quasi dengan desain uji sebelum dan uji sesudah. Hasil penelitian menunjukkan bahwa keahlian fungsional untuk nelayan wanita pada desa Bongo Provinsi Gorontalo dapat dilihat pada beberapa aspek berikut: (I) Penguasaan/pemahaman peserta didik (nelayan wanita pada Desa Bongo) terhadap materi ajar keterampilan fungsional istri nelayan dalam bentuk membuat kolombengi dengan rasa ikan, belajar membuat nugget ikan, dan praktik membuat stik jagung ikan. (2) Memahami istri nelayan Desa Bongo terhadap program pemberdayaan masyarakat dan peningkatan keterampilan siswa di bidang kewirausahaan, terutam dalam hal pengembangan bisnis dan administrasi bisnis. (3) Kemampuan peserta didik bekerjasama dalam kelompok usaha yang bisa menghasilkan produk dengan kriteria dan proses yang ada.
\end{abstract}

Kata Kunci: Pengelolaan Kewirausahaan, Komunitas Muslim Pesisit, Desain Eksperimen

Received : February 5, 20I7- Revised: April 26, 20I7- Accepted : Mei I0, 2017

Gorontalo State University

Email: abdulrahmat@ung.ac.id

DOI: I0.24042/febi.v2iI.943 


\section{A. INTRODUCTION}

The current reality shows that very high rates of unemployment are even more alarming and very limited employment there, it seems has been unable to awaken or inspire people to change their orientation. Government efforts to develop the entrepreneurial culture of the community, however, these efforts are still limited to the concept of developing a creative idea or the power of innovation and implementation is still very limited, so the real entrepreneurial activity is still low. The number of featured products in the local village of Bongo into a business that is able to create new jobs and welfare of themselves and their environment, so as to realize national independence. (Raharja, 2014).

Entrpreneur soul and spirit within every student is very important in order to create an independent human resources in thinking and action, able to apply science and technology for the benefit of themselves and society so as to achieve success in the future. Success takes sacrifice, hard work and patience. Succes can not just based on luck without trying, but requires effort and hard work, as Allah makes the Qur'an Surat ar-Ra'd verse II, which reads:

"Allah will not change the state of a people so that they would change the existing situation on themselves".

For the people of Bongo skills above aims to achieve four main things: (I) the target results: profit-material and nonmaterial benefits, (2) growth, (3) sustainability, (4) blessing. Target results: profit-material and benefit-nonmaterial, it means that the business is not only to seek profit (qimah madiyah or value of the materials) as high, but also must be able to obtain and provide benefit (profit or benefit) nonmaterial to the internal organization of the company and external (environment), such as the creation of a fraternal, social care and so on. Benefit, which is intended not solely provide material benefits, but also can be intangible (Wiklund and Shepherd, 2005).

Islam considers that the purpose of a charitable act is not only oriented to qimah madiyah. There are still three orientasilainnya, namely qimah insaniyah, qimah khuluqiyah, and qimah ruhiyah. With qimah insaniyah, means the manager seeks to provide humanitarian benefits through employment, social assistance, and other assistance. Qimah khuluqiyah, implies that the moral values mulian become a necessity that should appear in any business activities so as to create an Islamic brotherhood relationship, not just a functional or professional relationship. Meanwhile qimah ruhiyah mean the activity used as a medium to draw closer to Allah (Subanar, 2016). This improvement efforts should also be kept in the corridors of sharia, not justify any means (Cravens, 1997). 
Continuity, the target has been achieved with growth every year must be maintained so that the company can exis continuity in a long time. Blessings, all the goals that have been reached will not mean anything if there is no blessing in it. The effort then put the blessing as a core objective, because it is a form of receipt of all human activity. Blessing is a proof that the business carried out by a Muslim businessman has got ridla of Allah, and worth worship.

In Bongo are 850 heads of household, and every citizen celebrated by baking. Which is able to create ornate tolangga kolombengi and toyopo, there are hundreds who in the courtyard of the mosque. Each Walima average spend 500-800 Kolombengi. Besides cakes kolembongi also no corn flavor of the fish sticks. Corn Stick made from processed corn and fish that have been crushed with plus a little flour and spices as a supplement. The best raw materials used to make fish paty are the types of fish that have thick flesh is white and has a soft texture. Paty fish can be stored for a maximum of 6 days in the freezer. The results of observations available also nuggets taste of fish.

Business goals are; I) Achieving a market share of $20 \%$ in six (6) districts / cities in Gorontalo in the second year, 2) Achieve Payback Period (PP) in the second year, 3) Being a market leader (market leader) in the fifth, 4) Have employees from surrounding communities that do not have a job (unemployed) and dropout (Eggers, et.al., 2012). The intended market segment includes the upper-middle class community in Gorontalo province, especially in the city of Gorontalo, Gorontalo Regency and Regency Bone Bolango. The target market is women and men, aged 6-45 years, the work of students (pupils and students), employee / employees / workers and the general characteristics of enthusiasts snacks (snacks). Market position (Positioning) is intended to put the products so ingrained in the minds of entrepreneurs putting the customer.In this case the product position as a challenger to the market or a market challenger. This means that the product is a fish stick maize challenger of other similar competitor products currently on the market. Promotion is one way of entrepreneurs to accelerate as well as introducing the products to consumers. This type of promotion that selected them; Personal selling, by way of Face-to-face selling, where entrepreneurs using agents marketers to offer products directly to consumers; Brochures or leaflets; Promotion through radio, distributing business cards, using 
banners or banners; Public Relations / exhibition; utilizing online media / social networking (Stambaugh, et.al, 2017).

\section{B. METHOD}

This research activity is designed to approach the research and development. Borg and Gall (1989) argues that the Research and Developmet is as a strategy that aims to develop and discover new knowledge through basic research. This study is also intended to answer specific questions about the problems of a practical nature through 'applied research'. Experimental design used in this research is quasi experiment with the design of "The One-group pre-test - Post-test Design" (Sugiyono, 2008). This study used a descriptive approach qualitative and quantitative research design and development written by Borg and Gall (1989). Research and Development is often called the $\mathrm{R} \& \mathrm{D}$ is a process of research that aims to develop and validate a product in the form of goals, methods, means, procedures, evaluations, both hardware and software. The final goal of the R \& D is the birth of new products to improve performance. (Hansen, et.al., 20II).

Steps in the process of research and development is known as the circle of research and development that consists of, (a) examining the results of research related to the product to be developed, (b) to develop products based on research results, (c) field test, and (d) reducing devisiensi found in the stage of field trials (Miller, 2007).

\section{RESULTS AND DISCUSSION}

Learning materials typical food production skills Gorontalo livelihood of fishermen in the village of Bongo women, include: entrepreneurship, Practice makes corn Kolombengi fish, Practice makes fish nuggets and fish corn Practice makes Stick. Mastery / understanding of learners towards the materials presented in the tables below. Based on the results of questionnaires, looks readiness of learners in starting material with good entrepreneurship as many as I5 people (75\%). While learners readiness entrepreneurial enough in receiving materials as much as 5 people (25\%). Furthermore, students who lack the readiness to accept no matter entrepreneurship. I6 learners or as much as $80 \%$ showing attention / motivation both in receiving materials entrepreneurship.

While four people (20\%) showed attention / motivation enough. Seen I4 learners or as much as $70 \%$ indicates the activity / participation both in receiving materials entrepreneurship. While $6(30 \%)$ showed the activity / participation are sufficient. Nnampak all students (20 people) or as much as I00\% showing good 
cooperation in accepting entrepreneurship material. This is certainly as one of the main capital in the process of empowerment of women in the fishing village of Bongo.

Based on the questionnaire, it appears all students (20 people) or as much as I00\% showing seriousness in a job well done in receiving materials entrepreneurship. 4.6, it appears all students (20 people) or as much as $100 \%$ indicates readiness well in practice make corn kolombengi fish. It appears all students (20 people) or as much as 100\% showing attention / motivation both in practice makes corn kolombengi fish. It appears all students (20 people) or as much as $100 \%$ indicates the activity / participation well in practice make corn kolombengi fish. There also appears to all students (20 people) or as much as I00\% showing good cooperation in practice makes corn kolombengi fish. I00\% showing sincerity in completing the task well in practice make corn kolombengi fish and have a good readiness in practice makes the fish nuggets. There were also all students (20 people) or as much as 100\% showing good sincerity in completing the task in practice makes Corn Sticks fish.

Learning material and community empowerment programs in the field of business skills training for women in the fishing village of Bongo, including community development, business development and business administration. Students understanding of the things mentioned above, served all students (20 people) or $100 \%$ indicates that both the material readiness of community empowerment. All students (20 people) or I00\% showing attention / motivation both on the materials community empowerment. Seen I4 learners or as much as $70 \%$ indicates the activity / participation both in receiving the materials community empowerment. The remaining 6 (30\%) showed the activity / participation are sufficient. Seen attention / motivation of learners in following material improvement with good efforts of I5 people (75\%). While learners attention / motivation is quite enough to receive this material as much as 5 people (25\%). Furthermore learners attention / motivation was lacking in accepting this material does not exist. Seen I8 learners or as much as $90 \%$ showing good sincerity in completing the task in business administration. The remaining 2 (I0\%) showed enough sincerity in completing the task.

Having previously learners are given a wide range of materials to give greater understanding of learners towards learning materials functional skills wives of the fishermen in the form of entrepreneurship, practice makes kolombengi taste of fish, practice makes fish nuggets and practice makes sticks corn fish, as well as the understanding of women fishing village of Bongo to Increased community 
empowerment programs and skills of students in the field of entrepreneurship, especially in terms of business development and administration effort, it would require a specific assessment of the process of a product that will be produced by learners.

Learners will be divided into 3 groups, each group will create and work on their own material to the final product. Previous learners have also been prepared equipment and materials required. (a) Kolombengi Corn Fish. Tools needed: a stove, oven, cake printing equipment, mixers, spoons, scales and baking. Materials needed: flour, corn flour, tuna, sugar, salt and eggs. Results of the assessment of learners who joined in the manufacture of corn kolembengi said to be excellent fish from the stage of the process to the resulting product. By getting a total value of 47 out of a maximum score of 48 , or can be said to achieve success percentage of $98 \%$. Just get the value of 3 in the aspect of preparation especially where any accuracy criteria. (b) Fish nuggets. Tools needed: stove, pans, plastic containers, blender, mixer, scales, mold / pan, cutting board and knife. Materials needed: fish, wheat flour, onions, garlic, carrot, pepper, salt, bread, flour bread crumb and milk cans. Results of the assessment of learners who joined in the manufacture of fish nuggets said to be excellent on the stage of the process to the resulting product. By getting a total value of 47 out of a maximum score of 48 , or can be said to achieve success percentage of $98 \%$. This group scored 3 on aspects of the preparation, especially the criteria of timeliness back a few minutes. (c) Corn sticks. Tools required: the stove, pots, pans and knives. Materials needed: tuna, corn, tapioca flour, eggs, sugar, salt, garlic and oil. Results of the assessment of learners who joined in the manufacture of corn sticks very well be said of the stages of the process to the resulting product. By getting the maximum value of 48 , or can be said to achieve a I00\% success rate.

The discussion in this report, are intended to interpret the results of research that has been described above, by comparing the results with indicators of success. What is meant by describing the data is to describe the existing data in order to obtain the real form of the respondents, making it easier to understand researchers or others who are interested in the results of research conducted. Describe the information of these respondents are of two kinds. If the data is qualitative data, then the description of the data is done by arranging and classifying data, thus providing a real picture of the respondents. If the data is in the form of quantitative or transferred in the figures describe how the data can be performed using descriptive statistics. Data analysis is the simplest and often used by researchers or developers is to analyze the existing data by using the principles of descriptive. 
(Casson, 1992). By analyzing this descriptive they can present a brief, simple, and easier to understand. Which included descriptive analysis in general, including measures of central tendency, measures of variability, measures the relationship, measuring the ratio and measure the position of a score. Function description of the data is to administer and display a summary that is making it easier for other readers understand the content and meaning of the data view. (Cravens, I997).

Before the discussion of the results of the study, the following was stated indicators of success as follows: (I) The level of mastery of learning functional skills in women of fishermen in the village of Bongo District of Gorontalo Regency Beach Batudaa through the manufacture and processing of corn kolombengi fish, fish nuggets and corn sticks. Judging from these variables, then learning can be said to be effective, if $80 \%$ of learners master all / most of the learning materials. (2) Establishment of an independent business group with a superior product that is different, so it can foster a healthy competitive climate in trying and see the market opportunity. The ability of learners to the prior model of functional skills programs for women fishers (pretest) increased after the model program of functional skills. Although for 4 students (20\%) had no effect at all with their program's model of functional skills, but an outline visible improvement of skills for I6 other learners, or as much as $80 \%$. That skills vary widely, ranging from I to 17 points.

This is most noticeable on Learners number I and I5 with the increase reached 17 points. This will encourage the learners skills that can later be shared with other fishermen woman, so that the skills acquired learners can thrive through the business groups that can produce excellent products respectively. So the model of skill for a woman fisherman in the village of Bongo District of Gorontalo Regency Beach Batudaa was successful.

\section{CONCLUSION}

The model of functional skills for women of fishermen in the village of Bongo district of Gorontalo, can be seen from several aspects, namely: (I) The control / understanding of learners (female fisherman in the village of Bongo) of the learning materials functional skills wives of the fishermen in the form of entrepreneurship, practice makes kolombengi the taste of fish, practice makes fish nuggets and practice makes sticks corn fish, (2) understanding wives of the

fishermen village of Bongo towards community empowerment programs and Improved skills of students in the field of entrepreneurship, especially in terms of business development and business administration, and (3) the ability of learners 
cooperate in a business group that can produce a product with the criteria and processes in place.

In connection with this, it is necessary to publish this model in order to be a reference, referral and guidance to all stakeholders in planning, organizing, implementing and controlling the implementation of the program. The program is expected to accelerate the settlement of social problems, especially to reduce unemployment and alleviate poverty, in order to achieve a more prosperous Indonesian society, just, and dignified.

\section{REFERENCES}

Borg, W.R. \& Gall, M.D. (I989). Education Research. New York: Longman. Casson, H. (1992). Sukses Menjual. Jakarta: Pustaka Pembangunan Swadaya Nusantara.

Cravens, D.W. (1997). Strategic Marketing. Chicago: The Mc. Graw Hill.

Eggers, F., Hansen, D.J., \& Davis, A.E. (2012). Examining The Relationship Between Customer and Entrepreneurial Orientation on Nascent Firms' Marketing Strategy. International Entrepreneurial Management Journal. 8: 203-222.

Hansen, J.D., Deitz, G.D., Tokman, M., Marino, L.D., \& Weaver, K.M. (20II). Cross-National Invariance of The Entrepreneurial Orientation Scale. Journal of Business Venturing. 26: 6I-78.

Stambaugh, J.E., Martinez, J., Lumpkin, G.T. \& Kataria, N. (2017). How well do $\mathrm{EO}$ measures and entrepreneurial behaviors match? International Entrepreneurship Management Journal. I3 (3): 70I-720.

Miller, K.D. (2007). Risk and Rationality in Entrepreneurial Processes. Strategic Entrepreneurship Journal. I (I-2): 57-74.

Raharja, P. (20I4). Teori Ekonomi Makro Suatu Pengantar. Edisi III Jakarta: LPFEUI.

Subanar, H. (2016). Manajemen Usaha Kecil. Yogyakarta: BPFE-UGM

Sugiyono. (2009). Metode Penelitian Pendidikan. Pendekatan Kuantitatif, Kualitatif dan $R D$. Bandung: Alfabeta.

Wiklund, J. \& Shepherd, D. (2005). Entrepreneurial Orientation and Small Business Performance a Configurational Approach. Journal of Business Venturing. 20 (I): 7I-9I. 